\title{
PRESECULAR CHARACHTER OF MONTENEGRIN LAW ON FREEDOM OF RELIGION IN CONTEXT OF FULLER'S DEMANDS FOR INTERNAL MORALITY OF LAW
}

\begin{abstract}
The authors analyse the new Montenegrin Law on Freedom of Religion or Belief and the Legal Status of Religious Communities from two aspects: the aspect of the socio-political context of its adoption (material sources of law) and formal aspects of the provisions of the Law itself (formal source of law) in order to point out the serious imperfections of that Law. Regarding the first aspect, wider social context in Montenegro is analysed in comparison with European regulative principles of area of religious freedoms. As for the provisions of the Law itself, they are considered in the context of Fuller's theory of the internal morality of law and its 8 requirements that make law possible in order to examine in detail whether and to what extent the Law fulfils the principles of legality as a basic principle for realization of the rule of law. The conclusion of the analysis from both aspects is that the analysed Law is also full of imperfections and obviously incompatible with the values of the rule of law.
\end{abstract} secularity.

Keywords: morality of law, Fuller, Montenegro, Law on freedom of religion, post

\section{Introduction}

The new 2020 Law on Freedom of Religion or Belief and the Legal Status of Religious Communities (hereinafter the Law) came into force in a tense atmosphere. The clearly expressed disagreement with the proposed solutions in this Law, which was repeated several times before by representatives of the opposition and highly ranking clergy and believers of the Serbian Orthodox Church (hereinafter SOC) as the largest religious community in Montenegro, after the resistance on the night of the vote, turned into massive and peaceful protests. The Law provisions and the motives for its adoption have been the most important legal and political topic of Montenegrin public discourse in recent months and the key factor that contributed to the political changes that followed the August 2020 parliamentary elections. At the time of writing of this article, it is predictable

\footnotetext{
* PhD, Senior Research Associate, Institute of Comparative Law, Belgrade, Serbia, e-mail: v.djuric@iup.rs

${ }^{* *}$ LLB, Master's student at University of Belgrade, Faculty of Law, Serbia, e-mail: vasilije.markovic227@gmail.com
} 
that the provisions of the Law that has been considered controversial and which are still in force will be abolished or at least revised. That will put an end to the process that has lasted since the publication of the Bill. In that sense, the relevance of this article lies, although the Law will soon be revised, in the exposure of the all unsustainability of certain legal solutions from one slightly different, theoretical angle.

The methodological approach that has been chosen in this article covers the entire phenomenon of this act - from social facts and political forces and motives as material sources of law that determined this act to the treatment of the provisions of the act itself as a formal source of law, with the unique aim of presenting in toto its retrograde nature in both these aspects. Retrogradation within the material sources of law could be seen as rough interference in the most refined issues of church self-determination and identity in the context of church-state separation. Instead of promoting what de la Ravière, the French physiocrat, summed up through the sentence "to attack property means to attack freedom $[\ldots]$ and that the fight for one's security, property and freedom should be the primary reason for all laws" (according to Tadić, 2006, pp. 98-99) this act in fact is the emanation of quite the opposite direction, because some of its provisions violate the right to peaceful enjoyment of property and the right to freedom of thought, conscience and religion - two cornerstones of the law and legal security and liberal democracy. Its property provisions on ex lege nationalization of church property nullify the legal reality. The registration provisions reduce SOC's acquired rights to their abolition and make the Law to abolish even the ideality of law which, according to Tadić (2006, pp. 248-249), is expressed in a legal entity whose essence lies exactly in self - determination and autonomy.

\subsection{Why Fuller?}

Before further elaboration it is necessary to make another methodological note regarding our determination to "pass" the Law and its disputed provisions through the "test" established by L.L. Fuller in his book Morality of Law. There are multiple reasons why Fuller's teaching was so suitable for the analysis of the provisions of the Law. Few apologies of such legal solutions were reduced in the previous period to one single positivistic argument - the period of vacatio legis has passed, ergo the Law has become part of the Montenegrin legal system and there is nothing left to do but to obey it. ${ }^{1}$ To oppose such a truncated ${ }^{2}$ positivist

\footnotetext{
${ }^{1}$ An example of such attitude can be seen here: https://www.youtube.com/watch? $\mathrm{v}=0 \mathrm{kXnf5gXmbw \& t=1804s,}$ accessed 11 9. 2020.

${ }^{2}$ Truncated because this attitude, taking into account the atmosphere and the course of the legislative process in this concrete case, does not fulfil the basic and minimalist positivist principle according to which the law is to be considered an act that has been adopted by a valid procedure in accordance with legislation rules. But that was not the case here. The entire legislative process was accompanied by: failure to organize public debates on the 2015 Draft Law, and there was a complete lack of public and inclusive public consultations on the Bill, primarily with religious communities as direct addressees of this Law, which was act of noncomplying with the recommendations given by the Venice Commission (2019, p. 7, par. 22), also the non-transparency of the process could be seen in the fact that the identity of the members of the working group that wrote the law was not disclosed to the public, and in the end the very act of adopting the law was accompanied by constitutionally dubious detention of MPs from opposition without lifting their immunity first. The position
} 
attitude anyone from the plethora of authors of essential jusnaturalism would simply not be purposeful. Arguments and criticisms from the point of view of natural law might be quite appropriate, but they would miss the point. Instead of this inadequate dichotomy of positive and natural law, Fuller creates, by his own confession, special, procedural version of natural law, which tends to describe the endeavour of subordinating human behaviour to the rule of law and whose naturalness is reflected in purpose and permanence just as much as the carpenter or any other craftsman uses natural laws in his endeavours (Fuler, 2011, p. 105). To this goal law is dedicated as an endeavour - an endeavour to achieve the fullest possible legality, and what is especially important for the issue that we deal with in this paper is the fact that Fuller's idea of procedural jusnaturalism is completely secularized and deprived of any metaphysical or divine background or cause, and concentrated only on practical activity of a person i.e. legislator (Budisavljević, 2017, p. 190), since Fuller was one of those people who rejected traditional religious approach of natural law theories (Summers, 1984, p. 64). Therefore, it is a particularly tempting challenge to show within the framework of such Fuller's theory, the whole unsustainability of legal solutions related to the position of religious communities and to refute the criticism that the SOC in Montenegro is acting like it is placed above legal order and the state by invoking some of its divine prerogatives.

Fuller's guiding idea comes down to the view that for the rule of law it is necessary to respect procedure, institutions and form, and that, therefore, this internal morality is a necessary precondition for the successful realization of the essential aims of law. Vice versa, if there is no such presumption, which is embodied in eight requirements or qualities that the law must fulfil, there will be no talk of bad law, but the law will not exist at all (Đurđić, 2008, p. 76). ${ }^{3}$

And finally, equally important reason that led us to reach out for Fuller's procedural jusnaturalism is that we have recognized in Fuller's story about a fictional country and its equally fictional ruler Rex who takes on the ambitious task of a legislator the striking level of similarity with the authorities of Montenegro. ${ }^{4}$ The casuistry combined with the

reached by the mature Radbruch that equalization of force and law nullifies the character of an Act as part of the rule of law and the law then becomes violent in spite of its correct form (Vasić, 2018, p. 52) remained unattainable in this situation because even the form was not properly respected. Therefore, there can be no question of what Fuller calls parliamentary sovereignty, which is only a more refined formulation of the positivist apologies of this law that we criticize, because when asked whether the state gives parliament unbridled power to go against its own laws that still exist in the legal order, Fuller answers in the negative because, as he states, the parliament is limited by the law of its own internal procedure (Fuler, 2011, pp. 49, 123).

\footnotetext{
${ }^{3}$ Even the authors who criticize Fuller's views gave him the credit for the affirmation of necessary connection between law and moral through control by rules. That control was considered as request of justice, i.e. legality principle (Hart, 1994, p. 207). Furthermore, Fuller's minimalism of morality (Mitrović \& Vukadinović, 2017, p. 12) is in many ways complementary with the standards and understanding of the law that the European Court for Human Rights has later developed in its practice (Marinković, 2018, p. 323) and thus, taking into account Fuller's theory regarding Montenegrin law becomes even more relevant if it is known that Montenegro has ratified the European Human Rights Convention (ECHR) and is part of the human rights protection system whose ECHR is a crucial factor.

${ }^{4}$ President of Montenegro expressed politically motivated desire to work until his last breath on reorganizing the church structure for which purpose this Law should serve on the legal ground (RTS, 2020a).
} 
Rex's scarce legal knowledge from Fuller's allegory (Marinković, 2018, p. 327) and the no less incompetence of the Montenegrin authorities ultimately had an identical result: legal solutions, in both imaginary and real case were such that they could hardly be understood by either a layman or a legal expert (Fuler, 2011, p. 51).

\section{Presecular character of the political and legislative process}

The ruling party announced at the 2019 party congress that one of their future priorities will be to restore the autocephaly of the Montenegrin Orthodox Church (see Mandić, 2019) in order to overcome the situation of division among the Orthodox population in Montenegro by forming a unique and organizationally independent Orthodox Church (Democratic Party of Socialists, 2015). The existence of such a political aspiration of one of the political parties is (il)legitimate in a pluralistic society, but the legal implementation of such an idea certainly causes multiple difficulties, both in terms of the constitutional order of Montenegro and in wider European framework. One of the basic principles that act like the Law should promote is the respect for the legal self-determination right of the church, which has its correlate in the obligation of the state to recognize and protect that right (Šijaković, 2011a, p. 456). It is important to emphasize that, philosophically speaking, regarding that recognition the state does not produce ontological reality but legal reality (Šijaković, 2011b, p. 466). Therefore, legally speaking, the character of such recognition remains exclusively declarative. This principle was roughly violated by the adoption of the provisions which purpose is to be a lever of interference in the deepest issues of church identity, organization and self-understanding. The product of such state intervention would be a religious entity which, in terms of nationalist projections and cooptation (which according to Pedro Ramet are two of the three key characteristics behind modern demands for autocephaly, (stated according to: Jevtić \& Veković, 2019, p. 599)) would in everything be servile to the postmodern autocracy in Montenegro (Šijaković, 2011a, p. 455). The intention to reorganize the church structure (i.e. to establish a new one) is in clear contradiction with the constitutional principle of separation of state and church (Art. 14 of the Constitution of Montenegro) a principle that is also one of the most significant civilizational achievements of modern Europe. Therefore, this Law is a major step backwards in relation to the proclaimed aspiration to achieve European values. Instead of considering becoming a part of post-secular Europe, Montenegro with such a Law remains stuck with pre-secular topics.

Such conclusion can be also reached in the field of another important principle of state-church relations - the principle of neutrality. The principle of state neutrality in the case law of the European Court of Human Rights (ECHR) implies that the autonomy of religious communities is an integral part of pluralism in democratic societies (Supreme Council of the Muslim Community v. Bulgaria), as well as that they must not support one of the conflicted parties and in cases of the division and conflicts between two groups within the same religious community. So the state must maintain its neutral character even at the cost of political tensions which are, in fact, an inevitable consequence of pluralism. The role 
of state authorities in such cases is not to eliminate the cause of tension, thus eliminating pluralism, but the mutual tolerance of the opposing groups (Sheriff v. Greece). What contribution can be made to the principle of neutrality when the Law, whose provisions and the manner and motives for its adoption do not show that the goal is to eliminate but on the contrary, to induce tensions and undermine pluralism? This is all the more so because the ECHR cited case law referred to those cases when, within the factual situation, there were indeed serious legal and dogmatic disputes between two fractions, both seriously claiming the right on the legitimacy and heritage of the religious community. None of that is the case in Montenegro, since there are no disputable issues in the field of church life and the dogmatic-canonical field. ${ }^{5}$

More than a decade ago, prof. Tanasković (2009, p. 78) was the first to present a thesis and define the ambience of legal regulation of the position of churches and religious communities in Montenegro as an ambience of pre-secularism as opposed to the tendencies of post-secularity that characterized Europe. He saw the reasons of pre-secularity or the gap in relation to the European legacy, in state-national (or nationalist?) reasons and post-communist heritage. Unfortunately, the events that followed, which culminated in the adoption of the Law in the described atmosphere showed that Professor Tanasković was right.

\section{Montenegrin Law on freedom of religion and requirements for internal morality of law}

The internal morality of law covers both types of morality by Fuller- the morality of duty (embodied in prohibitions) and the morality of aspiration (embodied in affirmation

\footnotetext{
${ }^{5}$ To make the absurd even bigger and the situation to get discriminatory tones, Montenegrin state authorities knew how to show maturity and understanding of these principles, respecting autonomy on the example of other religious communities. Thus, for example, the text of Article 5 of the Agreement on the Regulation of Relations between the Islamic Community and the Government of Montenegro can be illustrative, because stipulates that free regulation of the internal organization of the Islamic Community in Montenegro and establishment, change and abolition of legal entities belongs exclusively to the Meshihat (emphasis added) and in paragraph 2 that Montenegro guarantees the right of the Islamic community in Montenegro to freely communicate and maintain ties with Islamic communities in other countries, especially respecting the historical ties with the Islamic community in the Republic of Turkey. Such a text really represents fulfilled high standards and an example of good practice, but the question justifiably arises why an identical or at least similar agreement was not signed with the Serbian Orthodox Church. The reasons for endangered national security, which will be discussed below, which are offered in response, can hardly be a valid justification since this reason is not mentioned as one of the possible grounds for restricting the right to freedom of religion from Article 9 paragraph 2 of the ECHR, and the European Court in its judgment in the case of the Metropolitan Church of Bessarabia and others v. Moldova, based on its position on the text of the Convention, confirmed that reasons of national security, especially if not substantiated by convincing evidence, could not be grounds for restricting religious freedom (cited according to Marković, 2020, p.120). Of course, in this case in Montenegro we cannot talk about evidence, let alone evidence that would be confirmed and convincing about the alleged threat to national security by the Serbian Orthodox Church, but mostly it came down to unfounded political assessments supported by discriminatory intentions. In this way, the standpoints of the UN from 2011 were ignored, according to which discrimination against religious communities is prohibited, especially if it is carried out with the aim of bringing churches and believers who are considered not to correspond to the state's religious or political program under control (OHCHR, 2011, par. 57).
} 
and creation). Although the second predominates, both aim to enable the realization of not just any but good legal system (Đurđić, 2012, p. 707). That is why the provisions of the Law will be analysed in the context of both types of claims, with special emphasis on the two most problematic groups of issues - those dealing with the issue of legal subjectivity and those dealing with the property issues.

\subsection{Generality}

The generality of a legal act is considered to be the primary and fundamental aspect of the principle of legality. Fuller's standing point regarding this requirement of the internal morality of law is that the generality is satisfied if the rules exist (Fuler, 2011, p. 61). Thus, at first glance, it could be said that the fact of the existence of rules prescribed by this Law means that the generality requirement in this case is satisfied, especially since in Fuller's view equal treatment that can be subsumed under the existing norm is not generality but fairness (Đurđić, 2008, p. 62). But this is prima facie inference, since the requirement of generality has other qualities that must not be ignored. Thus, it is a condition for the effectiveness of the rule of law and the impartiality of the legislator, and more precisely, a condition and guarantor of the protective effect of a law whose injustice is being amortized by the generality (Đurđić, 2008, p. 62). Also, generality is a feature that prevents law's effect on certain goals and individuals from being known in advance (Hajek, 2012, p. 119). Closer look at certain legal solutions will show that the request of the generality has not actually been fulfilled in the case.

The Registration section of the Law (Article 18-34) and especially Art. 25, par. $3^{6}$ which carries the danger of abolishing the legal personality of the SOC, as well as Article $62^{7}$ which provides ex lege nationalization of religious buildings achieved only apparent abstractness of norms since their effect is to hit only the SOC in Montenegro as one of the addressees of this Law. This is because with other religious communities agreements have been signed. ${ }^{8}$ By these agreements the legal personality of those communities have been recognized and even the public law subjectivity of these communities, as the provisions on restitution implicitly recognize their property rights before 1945 and communist

\footnotetext{
${ }^{6}$ It stipulates that a part of a religious organization whose centre is abroad and who operates in Montenegro may acquire the status of a legal entity by entering it in the Register or Evidence [underlining ours], by which is excluded the possibility that a religious community based abroad in Montenegro has had legal personality even before this Law, which would be confirmed by admission for entry in the Evidence (of already existing religious communities) in accordance with Article 24.

${ }^{7}$ It stipulates that religious facilities and land used by religious communities in the territory of Montenegro which is found to have been built or obtained from public resources or have been in state ownership until December 1, 1918 and for which there is no evidence of property rights, as cultural heritage of Montenegro, are the property of the state.

8 The Agreement on the Regulation of Relations of Common Interest (with the Islamic Community) and The Fundamental Agreement, which has the nature of an international treaty, since it has been signed with the Holy See, and the Catholic Church is example par excellence of a religious community that operates in Montenegro and has its headquarters abroad.
} 
nationalization. ${ }^{9}$ There is no doubt that these are quite sufficient guarantees in terms of protection from possible adverse effects of these articles of the Law, guarantees that the SOC has not been provided since it is the only existing religious community with which the Agreement on relations of this kind has not been signed. ${ }^{10}$ From the above said, it is obvious that such solutions and constellations of political and legal decisions entered into the domain of discrimination, and open opposition to Art. 8, par. 1 of the Constitution of Montenegro which prohibits discrimination on any grounds, but also Art. 17, par. 2 of the Constitution which guarantees equality before law regardless of any particularity or personal property. In addition, the presented facts and arguments seem sufficient to conclude that the requirements of the generality have not been reached, at least, in terms of ratione personae.

\subsection{Promulgation}

The request for promulgation can be considered fulfilled if the law has been successfully published or otherwise made available, with the aim that the addressees of the law adjust their conduct to the known rules (Đurđić, 2008, p. 63). If we know that this procedure was duly followed in the case of the Law in question, it seems that there should be no special dilemmas whether the Law has been properly promulgated. But, if we analyse this specific issue in a broader context, then the question could justifiably be asked whether the multiyear continuity of non-transparency of the legislative process we wrote about in previous sections could blur the seemingly clear picture of a complied with promulgation requirement. This is all the more so because the shortcomings of the legislative process in the form of closeness to dialogue and public debate on the proposed solutions have been continuously pointed out by the immediate addressees of the Law. It seems that the basis for such an extensive interpretation of the promulgation requirements could be found in Fuller himself, who writes "that laws should be published appropriately and therefore be subject to public scrutiny, which includes the kind of appraisement according to which they represent such laws that should not be enacted" (Fuler, 2011, p. 66).

\subsection{Clarity}

The requirement of clarity, i.e. the standard of a clear legal norm, is another crucial condition of legality. Here, Fuller emphasizes that a situation is possible that the legislator himself, by performing his activity, violates the legality principle. This happens in those cases when the legislator not only exceeds his constitutional powers, but also enacts unclear and/or unrelated legislation. Thus, Fuller concludes that ambiguity and incompleteness

\footnotetext{
${ }^{9}$ Moreover, particularly interesting in comparative terms is the provision from Article 10 of the Agreement on the regulation of relation of common interest between Montenegro and the Islamic Community which states that the existing property of the Islamic Community that is not registered at the time of signing the Agreement will be registered at the request of the Islamic Community.

${ }^{10}$ Reason for that as said by the people of the political leadership of the state, lays in fact that SOC is treated as a relic of the past which should have stayed there. See (IN4S, 2019).
} 
enable that even legislator and not only the administration or the court can make legality unattainable (Fuler, 2011, p. 77).

This requirement also has remained mostly unfulfilled by the provisions of the Law. Thus, as an example of unrelated legislative action, a systemic ambiguity can be attached, which is obvious if Art. 30, par. 1 and Art. 32, paras. 1 and 2 of the Law are brought in correlation. Namely, Art. 30, par. 1 prescribes numerous reasons why a religious community may be banned from acting, and Art. 32, par. 1 prescribes a procedure for banning activities if the legitimate goal is constrained in the interest of public safety, protection of public order, health or morals and rights and freedoms of others could not be achieved by milder measures of restraint. Furthermore, par. 2 of the same article states that before making a decision on prohibition, the court has the opportunity to give the religious community a reasonable deadline to harmonize its actions with public order and morals. It is not clear from the comparison of the text of the stated paragraphs whether in the prohibition procedure the court can leave an appropriate deadline in all the mentioned cases from par. 1 or only in two cases from par. 2 (Pravni savjet i grupa autora, 2019, p. 55) that are especially emphasised. Also, the cause of such special emphasis on certain reasons is further unclear, especially if it is known that the list of reasons from par. 1 is a standardized numerus clausus way of prescribing restrictive reasons, widely accepted in international human rights law.

These articles fall under the criticism from Fuller's point of view on another ground. Namely, in Art. 32, par. 2, the standard "appropriate deadline" is used without absolutely any closer indication on how much time is to be considered appropriate, which is only one of many other examples in this Law in which there can be unjustifiably wide discretion for, in this case judicial body, which could further serve to the arbitrary restriction of individual freedom (Đurđić, 2008, p. 68). Following up on Hayek's critical assessment of the role of hyper production of such uncertain legal standards in degrading the rule of law, Fuller rejects as risky a legislative policy that relies on a passive wait for administrative or judicial authorities to understand and apply a broad legal standard and recommends action in legislative "hall" (Fuler, 2011, p. 78). This is completely missing in the concerning case.

There is no more obvious example of lack of clarity strictu sensu than in one part of the Art. 62, par. 1, which states that religious facilities and land used by religious communities in the territory of Montenegro which is found to have been built or obtained from public resources or have been in state ownership until December 1, 1918, from the moment of entry into force of this Law shall be considered as state property. ${ }^{11}$ What is unclear to the point of complete obscurity in this article is that it is not known what the legislator meant by the terms of territory of Montenegro and the state. Namely, it is a notorious historical fact that the borders of the state of Montenegro have changed

\footnotetext{
${ }^{11}$ Arguments of linguistic interpretation lead to this interpretation of the provision because in the quoted paragraph was used the verb form of the present in the 3rd person plural, and it can be understood that church property which, according to the legislator, churches and religious communities only use, has become ex lege state property. In this regard, it is completely unclear what else, apart from the role of the "fig leaf", the procedure provided for in par. 3 of the same article should serve. In this envisaged procedure, equally vaguely, has been given priority to 2017 Administrative procedure Law over the 2004 Civil Procedure Law.
} 
throughout history. Therefore, the territory that is to today of the state of Montenegro includes parts that weren't recognized as pertaining to Montenegro's legal system before 1918. At the same time, it is equally unclear what is meant by the term citizen (whether only a citizen of the Principality and Kingdom of Montenegro or any person regardless of his citizenship) (see Stjepanović, 2019, pp. 911-914, 917, as well as Pravni savjet i grupa autora, 2019, pp. 151-155, 166) The striking lack of clarity of this provision thus leaves us with a difficulty in attempts to properly understand it, halfway between the unfounded expansion of its scope and the unexplained and insufficiently guaranteed particularism in application. The cited examples of incompleteness and ambiguity ratione territoriae have proved Fuller's remark that apparent clarity can be more harmful than sincere vagueness (Fuler, 2011, p. 77).

\subsection{Congruence between declared rule and official action}

The question of the existence of congruence between a declared rule and an official action is the most complex of all the requirements of the internal morality of law (Fuler, 2011, p. 92). This requirement status in Fuller's thought is deserved by its correlation with the refined issues of interpretation and the role of judges, but also because the consistent application of law and preservation of legal security through avoiding arbitrariness largely depends on it (Đurđić, 2008, p. 72). Fuller sees a dangerous threat to this principle in a number of reasons, from those concerning the text of law (such as misinterpretation or misunderstanding) to those concerning the characteristics of the people who are called to enforce the law (prejudice, corruption, drive for power) (Fuler, 2011, p. 93)

Ratio legis of the specific provisions of Law (Art. 62-65) show us how it looks when one of Fuller's fears comes true: it is not ambiguity as to the intent of the law itself, but the ambiguity which makes every later interpretive bravura useless (Fuler, 2011, p. 99). The deadline from Art. 63, par. 1 has not yet expired, so we have not reached to the official action from the declared rule. Despite that, the anatomy of provisions of Art. 62-65 together with the statements of high state officials, provide quite a sufficient ground for making a diagnosis on an interpretive level which reads: (clumsy) simulation of the ratio legis. What is this really about? The linguistic interpretation of the provision of Art. 62, par. 1 unequivocally leads to the conclusion that the ratio legis of church property nationalization ex lege is that the state considers it as its cultural heritage. This provision is an example of systemic inconsistency and is directly opposite to the 2010 Law on Cultural Heritage (see section 3.6). Instead of that, two explanations appeared in the public as the real ratio legis of nationalization of property, while at the same time there was no mention about them in the text of the Law. The first apology of ex lege nationalization referred to the need to correct the allegedly illegal entries of the SOC in the Real Estate Cadastre during the last decade of the 20th century, so that the order in that area could finally be restored (RTS, 2020b). The legislator ignored the fact that the $\mathrm{SOC}^{12}$ is not the only entity that submitted applications for entries under the then applicable laws and that there had been (and still

${ }^{12}$ But also other religious communities to which this Law should equally refer to. 
are) already valid positive legal regulations within the legal system of Montenegro to resolve this issue. Another apology, which was certainly the essential ratio legis of these provisions, is the process we briefly explained in the previous chapter. The state project of the restoration of the autocephaly of the Montenegrin church has been repeatedly underlined as the most important goal that this Law seeks to achieve and to which alleged corrections of the situation in the Cadastre and concern about cultural heritage should be subordinated. Therefore, the ratio legis of these provisions is inversely proportional to the presence of the reasons stated in the text of the Law. The exposed mimicry of the true intentions of the law, which came as a consequence of the insincerity of those who passed the Law, is additionally worrying if the following provisions (Art. 63-65) governing the procedure of determining and registering established state property are being observed in the context of the "due process of law". The procedural meaning of this remedy is a guarantee that no one can be deprived of property, among other things, except on the basis of law and in an impartial and fair procedure (Đurđić, 2008, p. 73). However, the allotted procedure in the provisions above guarantees quite the opposite. Because the principles of rule of law are seriously endangered by prescribing special and ad hoc administrative proceeding instead of regular litigation ${ }^{13}$, ignoring the rules on the burden of proof and violations of the right to a fair trial and equal access to court. The doubt in the impartiality of the administrative body that will conduct the proceedings supported is heightened even more by illegal examples in the past. ${ }^{14}$ Also, it was noted that the requirement of congruence was seriously brought into question both in terms of interpreting the intention of the law and in terms of the lack of due process of law.

\footnotetext{
${ }^{13}$ In that sense, the planned subsidiary application of the 2004 Civil Procedure Law after the 2017 Administrative Procedure Law does not fundamentally change anything and represents no more than a cosmetic change that should serve as proof that one of the sharpest criticisms in the Venice Commission Opinion from June 2019 on the text of Bill was implemented.

${ }^{14}$ The Orlandić case is illustrative not only because it shows how porous impartiality and trust in the administrative bodies of Montenegro are, but also because it reveals how unfounded is the procedure prescribed in these provisions of the Law. Namely, acting at the request of the Montenegrin Orthodox Church, the local real estate administration headed by Mr Orlandić unilaterally removed the Metropolitanate of the SOC as the titular of several religious buildings in Cetinje, arguing that the entries were illegal, which was a kind of avant-garde for the writers of the Law that was adopted more than a decade after this case. Then, acting on the appeal of the SOC, the Ministry of Finance, as the second instance body responsible for administrative control of the Real Estate Administration, annulled this unilateral decision of the Real Estate Administration and confirmed the ownership of the SOC, fully accepting the SOC argumentation. It is especially interesting that the Minister of Finance of the time stated that the issue of ownership could not be resolved in an administrative procedure, but only through a regular litigation, before a competent court (PCNEN, 2008). Today, the most important arguments of the SOC, which are critical of the disputed provisions of the Law, are based on the identical position, and this position was also confirmed by the Supreme Court of Montenegro in the verdict regarding the determination of property rights, no. 244/18 from 10 May 2018, in which, after emphasizing the importance of the rebuttable and presumption of accuracy of entry in the real estate cadastre, Court emphasized that the administrative body is not authorized to determine property rights, since that is in the jurisdiction of the court. The unequivocal position of administrative and judicial practice in these matters, which we have just presented, only further confirms what devastating consequences for the legal security and logic of the legal system of Montenegro are produced by the disputed solutions of the Law on Freedom of Religion.
} 


\subsection{Prohibition of abuse of retroactive legislation}

Fuller believes that the most obvious and at the same time the most difficult problem of the legality and morality of law and its realization is the requirement that the rule adopted today should govern what happens tomorrow and not what happened yesterday (Fuler, 2011, p. 59). The requirement of prospectivity is so important for legal certainty, that according to some theorists, the retroactive force of law is "assassination of the law and the devastating force of the social contract [...] and that retroactivity is the force that deprives the law of its character" (cited according to Đurđić, 2008, p. 65) Fuller, however, while remaining an advocate of prospectiveness as an important segment of legality, is not so exclusive in his critique of retroactive legislation. Namely, he believes that retroactive regulation can be used as a "curative" law that is appropriately designed to correct shortcomings in the exercise of power (according to Fuler, 2011, p. 69). Thus, retroactivity can be a suitable mean of correcting possible antinomies among other demands of inner morality. Therefore, it was more appropriate to name the section dealing with this inner morality requirement - "prohibition of the abuse of retroactivity" instead of the prohibition of retroactivity of the law in general. In that sense, whether the undisputed retroactive character of this Law, based on everything presented so far, was adopted as a curative measure or as an abuse of retroactivity.

The provisions in articles 62-65 of Law are par excellence retroactive as they prescribe proceedings regarding legal acts and facts, some of which occurred more than 100 years ago and other more than 20 years ago. Retroactive regulation of these issues ignored the valid provisions of other laws that regulate institutes and deadlines after which the subjects of the Serbian Orthodox Church unequivocally became the owners of the facilities targeted by the analysed provisions. Only some of the institutes that have been skipped in this way are the institutes of acquisitive prescription (Art. 53, par. 2 and Art. 54, par. 2 of 2009 Property Law) and the action for cancellation of title (Art. 124a of the 2007 Cadastre Law), and their negligence further undermined legal certainty and confirmed the absence of a curative character in the retroactivity of these provisions. Furthermore, the implicit mandatory request of registration of SOC subjects under Art. 25 of the Law retroactively seeks to diminish their rights acquired by using the non-registration option granted by the previous law from 1977, which hereby has implicitly recognized the continuity of legal subjectivity for SOC subjects.

The lack of curativeness of this retroactive provision is also reflected in the fact that it ignores the suggestion from the joint guidelines of the Venice Commission and the OSCE-ODIHR (Venice Commission, OSCE/ODIHR, 2014) that underline that restrictions must not be retroactive or arbitrary towards a particular group or individuals (par. 7) and that, when it comes to the registration, the transition to the new legal solutions must be adequate, i.e. it must not diminish or abolish rights acquired under the previous law (par. 36). Finally, the Constitution of Montenegro in Art. 147, par. 1 prohibits the retroactive effect of laws and other regulations, except in the case of certain provisions of the law if it is required by the public interest which has been established in the procedure of 
enactment of the law (par. 2). Therefore, neither of the above-mentioned paragraphs of the constitutional norm can justify the retroactive character of certain provisions of the Law. Quite the opposite, because it is difficult to say that the public interest was established when the entire legislative process was burdened by non-transparency, lack of dialogue and confusion about the real intention of the law, as described in the previous section. In addition, if the real intention of the Law was to restore the position of Church like it was before 1918, the question of the legitimacy of such an intention as a public interest can also be raised. Why would such a retroactive intervention in the period of more than a century ago be in the public interest, especially when today, more than century after 1918, many things are not the same: it is not the same character of Montenegrin statehood (see Raković, 2019), and neither is the constitutional position of churches and religious communities in Montenegro, which is even more important for this issue. ${ }^{15}$ From the above stated it is clear that the provisions of the Law with retroactive effect have neither constitutional reinforcement nor justification in the field of curative action and improving impact on other requirements of the inner morality of law.

\subsection{Contradictions in laws}

The enactment of contradictory and mutually inconsistent laws is considered very detrimental to the legality and efficiency of the legal system in toto (Đurđić, 2008, p. 70). If contradictions, however occur, what can be even more detrimental than the existence of legal contradictions is their inadequate treatment, which can be achieved, for example, by favouring a technical approach instead of comprehensive consideration of contradictory provisions from not only legal, but also from economic, political and sociological point of view (Fuler, 2011, p. 82). Fuller distinguishes two types of contradictions in laws. The first refers to the case of "self-contradictory law" and the second refers to the contradiction between two or more valid legal regulations (external contradiction) (Fuler, 2011, pp. 8081). Unfortunately, in the case of the analysed Law, both types of contradictions are present.

Examples of external contradiction are numerous and each of them seriously undermines the constitutional provision on the unity of the legal order from Art. 145 of the Constitution of Montenegro which, according to the interpretation of the Constitutional Court (Decision of CC, U-I no. 15/15, par. 7.3), implies "[...] the principle impossibility that a law governing one area changes certain legal solutions already contained in a systemic law governing that or another area". Thus, first of all, from the aspect of the previously processed request of internal morality of law, the disputed ratio legis of nationalization of facilities and land of SOC as a cultural heritage of Montenegro also encounters serious difficulties within this request. Namely, the provision of Law according to which religious buildings are property of the state because they are part of the cultural heritage is unsustainable if it is brought in connection with Art. 2, par. 2 of the 2010 Law on Cultural Heritage, which prescribes that a cultural good may be in state

15 Before 1918, Orthodoxy was the state religion in Montenegro, while today Montenegrin Constitution prescribes a model of separation, strict separation to be more precise. 
or private ownership. Thus, the regime of ownership obviously has no influence on the perception of an object as a cultural good. Additional confirmation of this interpretation can be found in Art. 3, par. 1 of the 2010 Law on Cultural Heritage, which stipulates that cultural goods are protected regardless of their ownership, or whether their character is secular or religious. Finally, in Art. 5, entitled "the right on cultural heritage" (a term used in Art. 62 of the Law as well), speaking first of the availability and use (and not possession) of cultural goods, the legislator in par. 2 especially apostrophizes religious communities when emphasizing their duty to respect the cultural goods of others as much as their own. The interpretation of the used possessive pronoun that can be offered is that it was used precisely to denote the ownership and not the cultural affiliation of the goods to one subject because they are available (for use) to everyone (Pravni savjet i grupa autora, 2019, pp. 158-159). That this interpretation is really well-founded can be seen from the fact that the whole Art. 5 is aimed at guaranteeing the general right of usage of cultural heritage but also from the fact that in addition to religious communities the obligation to respect the cultural goods of others remains imposed on all other subjects and legal entities. These arguments unequivocally point to the conclusion that the legislator here really has in mind ownership of cultural goods.

Furthermore, the procedure of entry of state property rights on religious facilities and land is envisaged by Art. 63 as a specific administrative procedure. This in itself would not be disputable if Art. 63, par. 2 of the Law complied with 2017 Administrative Procedure Law (hereinafter: LAP) which stipulates in Art. 4, par. 2 that the provisions of special laws adopted due to the specific nature of administrative matters in certain areas must not contradict or diminish the principles and objectives of the LAP nor reduce the level of protection of the rights and interests of the parties prescribed by the LAP. Unfortunately, the procedure provided for in Art. 63 violates the principle of the LAP contained in Art. 14 which refers to the protection of the legal interests of the parties and which stipulates that the party has the right to participate in the procedure to determine the circumstances relevant for administrative acts and has the right to state its position on the results of the examination procedure. Art. 63 stipulates the obligation of the state body to determine, list and submit a request for entry of state property rights in the real estate cadastre, and the real estate cadastre body is obliged to register the submitted request and inform the relevant religious community about it. Therefore, no obligations on the notification that the procedure is being conducted, including the possibilities for the participation of religious communities in the capacity of a party in the sense of Art. 51 of the LAP, are foreseen, but quit the opposite (Pravni savjet i grupa autora, 2019, p. 168). Among the major systematic inconsistencies, i.e. the examples of external contradictions, it is worth mentioning the absurd transfer of the burden of proof from the state as a subject that makes a request to churches and religious communities as legal holders, contrary to Art. 112 of the 2009 Property Law, then the contradiction with Art. 86, par. 2 of the 2007 Cadastre Law which stipulates that the entry of real estate rights must be done on a clear and unambiguous legal ground, which in case of application of such provisions of the Law would not be the case because 
there is obvious dispute about the legal ground, on which the administrative body is not authorized to make decisions ${ }^{16}$, etc.

We have example of internal antinomy in both groups of provisions that are analysed in the article (property issues provisions regarding registration). Both of these groups of provisions are contrary to Art. 14, par. 1 of the Law which prohibits any discrimination on the grounds of religion or belief. Thus, transitional provisions dealing with property issues are directly discriminatory in relation to religious communities because only for them as subjects, it is envisaged the transfer of ownership to the state through legislation and a special procedure for that purpose, characterized by a lower scope of legal protection than those which other subjects and legal entities have at their disposal. Moreover, bearing in mind that the differentia specifica of religious communities in comparison to other subjects in legal life is precisely the fact that their identity is based on religion and religious beliefs, it would mean that their differentiation and unequal position was made on basis that is strictly prohibited (Pravni savjet i grupa autora, 2019, p. 179). On the other hand, this and the previously elaborated provision from Art. 25, par. 3 of the Law even have the effect of indirect discrimination, because they target only the SOC and its subjects. The mentioned example of internal antinomy can, in certain sense, be considered as a meeting place of internal and external contradictions, because the above mentioned provisions are for the same reasons also contrary to Art. 2 of the Law on Prohibition of Discrimination and a constitutional provision from Art. 8 of the Constitution of Montenegro.

\subsection{Laws that are capable of being obeyed}

It is reasonable to expect that enacted laws put enforceable requests in front their addressees. Otherwise, not only would the balance of reciprocity in the contractual relationship between the Government and the citizen, on which Fuller relies on so much, be greatly disturbed, but the absurdity would reach a level at which one might wonder how a reasonable legislator, even if he was the most notorious dictator, would be able to pass such a law? (Fuler, 2011, p. 83). In order not to fall into the trap of easily characterizing a law request as impossible to obey, Fuller advises distinguishing it from a request that is obviously extremely difficult to fulfil, but apart from a slight hint that for this purpose we use assumptions about the nature of man and the universe, which, to make matters

\footnotetext{
${ }^{16}$ In the context of the mentioned provisions on the entry of state property rights on religious facilities and land for which there is no evidence of property rights, it would be very interesting to see how this provision of the Law would be interpreted in relation to Art. 10, par. 3 of the Agreement between the Islamic Community and Montenegro according to which the existing property of the Islamic Community which is not entried in the real estate cadastre will be entried at the request of the Islamic Community, but it is also stated that the property which is at the same time a cultural good (hence, only if such status is expressly prescribed and not presumed for all objects as can be interpreted from the Law) cannot be alienated or taken out of the country without the consent of the Government of Montenegro (par. 3) which is in fact, a reasonably justified and standardized restriction that actually confirms the existence of property rights of the Islamic community. Linking these provisions of the Law and the Agreement is multiply challenging, both in terms of the procedure of entry and interpretation of evidence of property rights, and in a broader and insufficiently processed theoretical context, in terms of understanding the hierarchy of legal acts and the place that such an act of contractual state-church law has within it.
} 
more difficult, are subject to change (Đurđić, 2008, p. 71), Fuller does not give any closer parameters for distinction and even has named that interspace as "indeterminate". Although our task is the most complex due to what has been stated here, we will try to point out two examples by which the Law violates the prohibition of demanding the impossible.

One part of Art. 62 which has already been cited several times, can hardly withstand the test of elementary logic and common sense from another aspect. Namely, when prescribing that cultural heritage is state property, the legislator used the phrase religious facilities and land. That part of the provision, as adopted, is grotesque and approaches level of absurdity from Fuller's rhetorical question because it makes Montenegro the only country in the world where land is considered as cultural heritage eo ipso (sic!) (Pravni savjet i grupa autora, 2019, p. 159). Another impossible situation that the analysed Law tries to induce is also related to the land mentioned in Article 62. Namely, the intention of that article is to transfer to state ownership the land owned by churches and religious communities (or only use them, from the legislator's point of view) because at one historical moment that land was a property of the state. Assuming that the land was indeed property of the state,$^{17}$ the essential intention of this article is then to actually nullify the effect of conversion that occurred by the moment of adoption of 2009 Property Law. Article 419 of this law stipulates that the right to use or permanently manage land in state ownership becomes the right of ownership of the previous holder of ius utendi (in this case, that holder are churches and religious communities) by the moment of entry into force of the 2009 Property Law, unless otherwise is prescribed by a special law. The Law pleads to be that special law, with a small problem of ten-year delay, because the only valid interpretation of the said provision leads to the conclusion that only this special law has the ability to prevent the effect of conversion - the constitution of property rights in full (plena in re potestas) over the land which was until then in property of the state, must have existed at the time of the entry into force of the 2009 Property Law. Therefore, such an attempt of acrobatics through the Law remains legally impossible (Pravni savjet i grupa autora, 2019, p. 159) because the opposite interpretation could even be understood as another example of inadmissible retroactive effect of this Law.

\subsection{Stability over time}

The permanence of law through time which is necessary in order that the addressees would be properly acquainted with their rights and obligations arising from the legal act so that they can behave accordingly, Fuller has brought in, viewing it as another requirement of the internal morality of law, in direct correlation with a ban on retroactive legislation. More precisely, he subsumed the damage caused by retroactive and frequently changed regulations under the same source which he named legislative instability (Fuler, 2011, p. 92)

In section 3.5. some of the harmful effects that occurred due to non-compliance with the requirement of the prohibition of retroactive legislation were analysed. As for the

\footnotetext{
${ }^{17}$ And there are serious arguments to the contrary regarding religious facilities and land, see Pravni savjet i grupa autora, pp. 131-147.
} 
requirement for stability over time, unlike the previous existing Law in this area, which lasted a full 43 years and for which can be said that has taken too seriously the requirement of stability over time, it seems that at a moment when all the bylaws have not yet been adopted and when less than a year has passed since the entry into force of the analysed Law, it is too early to take a position/stance on the fulfilment of this requirement. However, having in mind all the shortcomings presented in the previous sections, the question can be rightfully asked whether a future, already announced revision of the disputed solutions and thus disrespect of the requirement of stability over time, will in fact, paradoxically, be the most important contribution to the rule of law in this case?

\section{Conclusion}

This article has aimed to test and prove two hypotheses. The first referred to the retrograde character of the material sources of law that motivated and stood behind the Montenegrin Law on Freedom of Religion. This character has been confirmed by linking these sources with the basic postulates of regulating these issues in modern Europe, such as the principle of freedom of religion, neutrality and respect and recognition of selfdetermination of religious communities. It was confirmed that none of these principles were respected, and also it was pointed out that political and ideological motives that were strongly present during the entire legislative process and later can hardly find their place on the conceptual map of modern European achievements and values. The Law itself, as an act that is a formal source of law, is subjected to the test or requirements of the morality that makes law possible, starting from the belief that these requirements of internal morality are not a decor or some finesse that optionally adorns the power of law, but essential condition of that power itself (Fuler, 2011, p. 160). They were particularly adequate because they express, in the context of reciprocity which Fuller speaks of as an important balance that sustains the social contract, a true picture of the special relationship between the legislator and those whom the legislative undertaking relates to (Rundle, 2016, p. 504). Bearing in mind the significance of this argument, we performed a kind of "test" and with the offered explanations, determined that the analysed Law and its provisions did not fully or largely meet almost any of Fuller's requirements for the rule of law or internal morality of law. The true extent of the reasons for concern due to such conclusion can be seen if it is known that the scope of rule of law in a society depends on the realization of these principles of legality. To put it differently, the rule of law must not be equated with the validity of any but only of good (or moral) law, where the character of good or moral is manifested as gradation - through guarantee and realization of the minimum which requires that every law guarantees equality and adequate protection (Leposavić, 2019, p. 876). Thus, on such a scale of contribution to the existence of the rule of law, the analysed Law stays inadmissibly low.

However, one thing leaves space for moderate optimism, if we continue to look at the situation from the perspective of Fuller's jusnaturalism of the procedural type, and that is that such an unenviable place on the rule of law can be easily improved: by using 
precisely predicted forms and procedures in order to correct the errors embedded in each of the tested segments, one by one. And if the strengthening of the quality of legality through the fulfilment of each of the 8 requirements of the internal morality of law is upgraded by a transparent, inclusive and honest dialogue between legislators and addressees, then it can be witnessed the phenomenon of how something that was not or could hardly be considered as law acquired the character of law and how the idea of reciprocity, that very heart of the internal morality of law (Rundle, 2016, p. 500) gets its full reaffirmation. Achieving such scope of legal, but not only legal, progress in the field of religious freedom in Montenegro, about which Prof. Tanasković wrote with so much hope and optimism, depends so exclusively and solely on the standpoint to be taken towards the Law analysed in this paper. Presented position on this issue is in a complete accordance with what was written by the author whose work has been taken as the outline of this paper, both in methodological and content terms. Fuller wrote in his book that opposing laws that tend to impose religious or political beliefs are based on the understanding that such laws represent an unjustified interference with individual freedom (Fuler, 2011, p. 91). It has been confirmed that the struggle against such laws, which was relevant almost 60 years ago when the book Morality of Law was written, is still relevant today in Montenegro, as well as were confirmed words of reposed in the Lord Metropolitan of SOC in Montenegro, Amfilohije, who has rightfully denied legal character of this Law, naming it as "lawless law" (Vojinović, 2020).

\section{References}

Budisavljević, S. 2017. Principi moralnosti u jusnaturalističkoj misli Lona Fulera. Zbornik radova Pravnog fakulteta u Nišu, LVI (77), pp. 189-203.

Đurđić, S. 2008. Savremeni američki jusnaturalizam. Doktorska disertacija. Niš: Pravni fakultet Univerziteta u Nišu.

Đurđić, S. 2012. Fulerova moralnost koja pravo čini mogućom. Pravni život, 12, pp. 703-717. Hajek, F. 2012. Put u ropstvo. Beograd: Službeni glasnik.

Hart, H. 1994. The Concept of Law. Oxford: Clarendon press.

Fuler, L.L. 2011. Moralnost prava. Beograd: Pravni fakultet.

Jevtić, M. \& Veković, M. 2019. Render unto Caesar: Explaining Political Dimension of the Autocephaly Demands in Ukraine and Montenegro. Journal of Church and State, 61(4), pp. 591-609.

Leposavić, V. 2019. Univerzalne garancije zaštite prava svojine- slučaj Predloga zakona o slobodi veroispovesti Crne Gore i imovinsko pitanje. U: Čolović, V., Džomić, V., Đurić, V. \& Stanić, M. (ur.), Državno-crkveno pravo kroz vjekove. Beograd: Mitropolija crnogorsko-primorska, Institut za uporedno pravo, pp. 859-877.

Marinković, T. 2018. Pojam zakona u praksi Evropskog suda za ljudska prava. U: Vasić, R. (ur.), Nomotehnika i pravničko rasuđivanje. Beograd: Pravni fakultet Univerziteta u Beogradu, pp. 321-342. 
Marković, V. 2020. Legge sulla liberta di religione e/o la fede e sullo stato giuridico delle comunita religiose - summum ius summa iniuria. In: Vernole, S. (ed), La difesa della fede ortodossa in Montenegro- il possibile cambiamentogeopolitico nei balcani. Vincenza: CeSEM, pp. 113-131.

Mitrović, D. \& Vukadinović, G. 2017. Oblast prava i morala. Zbornik radova Pravnog fakulteta u Novom Sadu, 1, pp. 9-21.

Pravni savjet i grupa autora. 2019. Protiv pravnog nasilja nad vjerom. Cetinje/Berane: Mitropolija crnogorsko-primorska, Eparhija budimljansko-nikšićka.

Raković, A. 2019. Crnogorski separatizam. Beograd: Catena Mundi.

Rundle, K. 2016. Fuller's Internal Morality of Law. Philosophy Compass, 11(9), pp. 499506. doi: $10.1111 / \mathrm{phc} 3.12338$.

Stjepanović, B. 2019. Imovina SPC u svetlu člana 62 Predloga Zakona o slobodi vjeroispovesti ili uvjerenja i pravnom položaju vjerskih zajednica. U: Čolović, V., Džomić, V., Đurić, V. \& Stanić, M. (ur.), Državno-crkveno pravo kroz vjekove. Beograd: Mitropolija crnogorsko-primorska, Institut za uporedno pravo, pp. 905-921.

Summers, R. 1984. Lon L. Fuller. London: Edward Arnold.

Šijaković, B. 2011a. Država protiv Crkve: Crna Gora u tranziciji identiteta. U: Šijaković, B. (ur.), Ogledanje u kontekstu- o znanju i vjeri, predanju i identitetu, crkvi i državi. Beograd: Službeni glasnik, pp. 455-463.

Šijaković, B. 2011b. O načelima pravnog odnosa države i crkve u Crnoj Gori danas. U: Šijaković, B. (ur.), Ogledanje u kontekstu- o znanju i vjeri, predanju i identitetu, crkvi i državi, Beograd: Službeni glasnik, pp. 464-468.

Tadić, Lj. 2006. Filosofija prava. Beograd: Službeni glasnik.

Tanasković, D. 2009. Aktuelnost modela sekularne države u Evropi. U: Šijaković, B. (ur.), Pravni položaj crkava i vjerskih zajednica u Crnoj Gori danas. Nikšić: Bona fides, pp. 76-79.

Vasić, R. 2018. Pravna država i vladavina zakona: Šta pravna nauka "poručuje" nomotehnici.

U: Vasić, R. (ur.), Nomotehnika i pravničko rasuđivanje. Beograd: Pravni fakultet Univerziteta u Beogradu, pp. 17-67.

\section{Legal sources}

Administrative Procedure Law (Zakon o upravnom postupku, Službeni list Crne Gore, br. 37/2017).

Agreement on the Regulation of Relations between the Islamic Community and the Government of Montenegro (Ugovor o uređenju odnosa od zajedničkog interesa između Vlade Crne Gore i Islamske zajednice u Crnoj Gori 2012. br. 01-427).

Cadastre Law (Zakon o državnom premjeru i katastru, Službeni list RCG, br. 29/2007 and Službeni list CG, br. 32/2011, 40/2011 - dr. zakon, 43/2015, 37/2017 and 17/2018). Constitution of Montenegro (Ustav Crne Gore, Službeni list Crne Gore, br.1/2007 i 38/2013). Decision of CC, U-I no. 15/15 (Odluka Ustavnog Suda Crne Gore, broj U-I 15/15). ECHR, 1999. Case of Sheriffv. Greece, application no. 38178/97, decision from 26 January 1999. 
ECHR, 2004. Case of Supreme Holy Council of the Muslim community v. Bulgaria, application no. 39023/97, judgment from 16 December 2004.

Law on Cultural Heritage (Zakon o zaštiti kulturnih dobara, Službeni list Crne Gore, br.49/10).

Law on Freedom of Religion or Belief and the Legal Status of Religious Communities (Zakon o slobodi vjeroispovesti i/ili uvjerenja i pravnom položaju vjerskih zajednica, Službeni list Crne Gore, br. 74/2019).

Law on Prohibition of Discrimination (Zakon o zabrani diskriminacije, Službeni list Crne Gore, br. 42/2017).

OHCHR. 2011. Report of the Special Rapporteur on freedom of religion or Belief, A/ HRC/19/6, from 22 December 2011.

Property law (Zakon o osnovama svojinskopravnih odnosa, Službeni list Crne Gore, br. 19/2009).

Supreme Court of Montenegro in the verdict regarding the determination of property rights, no. 244/18 from 10 May 2018 (Presuda Vrhovnog suda Crne Gore, br. $244 / 18$ od 10.5.2018).

The fundamental agreement between Montenegro and the Holy See 2011. (Temeljni ugovor između Crne Gore i Svete stolice 2011). Avaliable at: https://www.gov. me/pretraga/106956/Temeljni-ugovor-izmedu-Crne-Gore-i-Svete-Stolice.html.

Venice Commission, OSCE/ODIHR. 2014. Guidelines on the Legal Personality of Religious or Belief Communities. Strasbourg, 16 June 2014, Opinion No. 673/2012, CDL$\mathrm{AD}(2014) 023$.

Venice Commission. 2019. Draft opinion on Law on freedom of religion or belief and legal status of religious communities, No. 953/2019 from 7.6.2019.

\section{Website references}

Democratic Party of Socialists. 2015. Program of Priorities, Democratic Party of Socialists of Montenegro. Available at: https://www.dps.me/me/program.page 14, (18. 9. 2020). https://www.youtube.com/watch?v=0kXnf5gXmbw\&t=1804s, (11. 9. 2020).

IN4S. 2019. Vuković sekularno: Obaveza DPS-a je da obnovi partijsku crkvu CPC. Available at: https://www.in4s.net/vukovic-sekularno-obaveza-dps-a-je-da-obnovi-partijskucrkvu-cpc/, (22. 9. 2020).

Mandić, S. 2019. Đukanović: SPC pokušava da čuva infrastrukturu "Velike Srbije". Available at: https://www.vijesti.me/vijesti/politika/388866/dukanovic-spc-pokusava-dacuva-infrastrukturu-velike-srbije, accessed 17. 9. 2020.

PCNEN. 2008. Ministarstvo priznalo Mitropoliji vlasništvo. Available at: https://www. pcnen.com/portal/2008/06/09/ministarstvo-priznalo-mitropoliji-vlasnistvo/, (27. 10. 2020).

RTS. 2020a. Đukanović: Do poslednjeg daha ću raditi na stvaranju crnogorske crkve. Available at: https://www.rts.rs/page/stories/sr/story/11/region/4033964/ djukanovic-crnogorska-pravoslavna-crkva.html, (17. 9. 2020). 
RTS. 2020b. Džomić: Crkva ima dokaze o vlasništvu pravoslavnih hramova u Crnoj Gori. Available at: https:/www.rts.rs/page/stories/sr/story/11/region/3854268/crna-gora-spc-zakondzomic.html?fbclid=IwAR0ikJ0LOFgusa4AwFFJeRPSBnRnShRPdJzcVp7AITo0alXLM_ nBa_z7k2Q, (23.9.2020).

Vojinović, R. 2020. https://svetigora.com/mitropolit-amfilohije-sa-litije-u-niksicu-povucitebezakoni-zakon-obraz-crne-gore-je-bitniji-od-svega/?script=lat, (28. 11.2020).

\section{Prof. dr Vladimir B. Đurić}

Viši naučni saradnik, Institut za uporedno pravo, Beograd, Srbija

e-mail:v.djuric@iup.rs

\section{Vasilije V. Marković}

Student master studija na Pravnom fakultetu u Beogradu, Srbija

e-mail: vasilije.markovic227@gmail.com

\section{PREDSEKULARNI KARAKTER CRNOGORSKOG ZAKONA O SLOBODI VEROISPOVESTI U KONTEKSTU FULEROVIH ZAHTEVA ZA UNUTRAŠNJOM MORALNOŠĆU PRAVA}

\section{Sažetak}

Autori analiziraju novi crnogorski Zakon o slobodi veroispovesti ili uvjerenja i pravnom statusu vjerskih zajednica sa dva aspekta: aspekta društveno-političkog konteksta njegovog usvajanja (materijalni izvori prava) i formalnih aspekata odredbi samog Zakona (formalni izvor prava) kako bi se ukazalo na ozbiljne nedostatke tog zakona. Što se tiče prvog aspekta, analizira se širi društveni kontekst u Crnoj Gori u poređenju sa evropskim regulatornim principima u oblasti vjerskih sloboda. Što se tiče odredbi samog zakona, one se razmatraju u kontekstu Fulerove teorije o unutrašnjoj moralnosti prava i njenih 8 zahteva koji čine pravo mogućim kako bi se podrobno ispitalo da li i koliko Zakon o slobodi vjeroispovesti ispunjava princip zakonitosti kao osnovno načelo za ostvarenje vladavine prava.

Ključne reči: L. L Fuler, moralnost prava, Crna Gora, Zakon o slobodi veroispovesti, postsekularnost.

Article history:

Received: 30 November 2020

Revised: 28 December 2020

Accepted: 20 January 2021 